\title{
What Have I Learned?
}

\author{
William E. Matthews, William Paterson University
}

E.J. (Roy) Knaus, (Email: knause@ wpunj.edu), William Paterson University

Do you remember our old marketing professor? What did we call him? "Tumbleweed" ... that was it because he always looked as if rolled across the prairie somewhere. He was good. One of the things I learned from him was that you should always ask questions. "You never know less than when you started," was his favorite saying. We'll over the last few days, I have asked a lot of questions. And my question is: what have I learned?

It was Tuesday evening in April 2003 and Peter Caswell and his good friend, Alan Dawes, were having a well-earned latte at the local Starbuck's. This was their regular racket ball night and they had played together virtually every Tuesday since they were roommates in college.

Peter continued:

As I mentioned a couple of weeks back, I received a call from a guy who does business brokerage with the information that the Brustlin Bottling Company for sale. I knew Tom Brustlin when I worked for my father. He's a nice guy but he must be in his late seventies now. So, I guess he's retiring and putting the business up for sale. Anyway, I went out and took a look at it. It is old but perfectly functional. And I think he's take \$250,000 for it.

So, I did some research on the bottling industry and also made calls to a number of local bottlers to get a feel for what's going on in the industry. The next step is to try to decide whether what I have learned is of any use. And where I go next. I feel I need to come up with a strategy.

\section{PETER CASWELL}

Born in November 1968 in Braintree, Massachusetts; Peter was the third and youngest son of the five children of Bob and Sue Caswell. Educated at Braintree High School, he started his college education at Northeastern University. However, at the end of his second year, he transferred to Duke University in North Carolina where he met Alan Dawes. On completion of a B.S. in business he then obtained a J.D. from the same institution. After a spell in Africa with the Peace Corps, he joined the law firm of Haskins, Ryker, and Eisen in downtown Boston making partner in 2000. Still single, he enjoyed a very comfortable existence living in a large house in Wellesley.

His friend Alan picks up the history:

When he was in high school and for the two years he was at Northeastern, Peter worked every holiday and weekends for his father who owned the Carteret Bottling Company. His eldest brother wasn't interested in the business. He went off to the West Coast and became a doctor. Mikey, the second son, was a real hippy and joined a commune somewhere out in Idaho. So, I think Peter always expected that his father would hand over the business to him. I think he saw it as his birthright. However, about a month before we graduated from Duke, his father sold the business. Peter was stunned. He didn't speak to his father for quite a long time. I think the sale of the business was what pushed him to go on and get a law degree.

He has been very successful with HRK. He is now their leading attorney in injury litigation and I wouldn't be surprised if he became the managing partner in the next two or three years. So, I was very surprised when he mentioned his interest in the Brustlin Bottling Company. If he were to take that on, it would mean a real change of direction for him. Maybe he's ready for a change. I don't know. 


\section{THE SOFT DRINK BOTTLING INDUSTRY}

In 2001, the retail sales of soft drinks in the United States totaled over $\$ 61$ billion with the average American consuming 53 gallons of soft drinks per person per year. The U.S. market includes nearly 450 different soft drinks. In 2000, 67.8 billion soft drinks were packaged in cans, 25.6 billion in PET (polyethylene terephthalate) bottles, and 0.08 billion in glass bottles.

Competition in the United States is broken down into three levels. The top level consists of manufacturers who are global behemoths. In 2002, they controlled $90.7 \%$ of the total market broken down as follows:

$\begin{array}{lll}\text { Coca-Cola } & & 44.3 \% \\ \text { Pepsi Cola } & & 31.4 \\ \text { Dr. Pepper/Seven-Up (Cadbury) } & 15.0 & \end{array}$

The second tier of companies consists of six national firms that account for a further $7.2 \%$ of the market as follows:

$\begin{array}{lc}\text { Cott Corp. } & 4.2 \% \\ \text { National Beverage } & 2.3 \\ \text { Big Red } & 0.4 \\ \text { Red Bull } & 0.1 \\ \text { Monarch Co. } & 0.1 \\ \text { Carolina Beverage } & <0.1\end{array}$

An estimated one thousand plus small local and regional firms share the remaining $2.1 \%$ of the market.

This same report indicated that the top ten brands, which accounted for $72.9 \%$ of the total market in 2000 , were as follows:

$\begin{array}{lc}\text { Coke Classic (Coca-Cola) } & 19.3 \% \\ \text { Pepsi-Cola (Pepsi Cola) } & 12.6 \\ \text { Diet Cola (Coca Cola) } & 9.0 \\ \text { Mountain Dew (Pepsi Cola) } & 6.4 \\ \text { Sprite (Coca-Cola) } & 6.2 \\ \text { Dr. Pepper (Cadbury) } & 5.9 \\ \text { Diet Pepsi (Pepsi Cola) } & 5.5 \\ \text { Seven-Up (Cadbury) } & 1.7 \\ \text { Caffeine Free Diet Coke (Coca Cola) } & 1.7 \\ \text { Diet Dr. Pepper (Cadbury) } & 1.1\end{array}$

According to the Beverage Digest, approximately $31 \%$ of all carbonated soft drinks are sold through supermarkets and $14 \%$ through vending machines. Fountain sales (i.e., restaurants) account for a further $23 \%$ with $6 \%$ going through mass merchandisers (such as K-Mart and Target), 5\% through convenience stores, and $4 \%$ through small grocers. That leaves approximately $17 \%$ going through gas stations, drug chains, gas stations/minimarts, airlines and other channels of distribution.

The three industry leaders maintain their position through extensive advertising and promotion. According to Advertising Age, PepsiCo (the parent company) spent \$2.21 billion on advertising in the United States in 2001 of which \$164 million were spent on its Pepsi and Diet Pepsi brands, \$136 million on its Gatorade sports drinks (and Prada bars), $\$ 62$ million on its Mountain Dew brand, $\$ 41$ million on Tropicana orange juice, 18 million on its Sierra Mist brand, and \$13 million on its Aquafina bottled water. By contrast, Coca Cola spent \$903 million of which \$224 million was spent on its Coke and Diet Coke brands and \$76 million on Sprite soft drinks, \$37 million on Minute Maid orange juice, \$26 million on Dasani bottled water, and \$23 million on its Powerade sports beverage. No 
information is available on Cadbury Schweppes' expenditures on its Dr. Pepper and Seven-Up brands in the United States.

\section{NICHE MARKETING STRATEGIES}

Recognizing from the start that he wouldn't be competing directly with Coca-Cola and PepsiCo, Peter concentrated on talking with those firms that had adopted a niche marketing strategy. Following are brief summaries of these interviews.* As Peter explains:

I wasn't interested in talking economic with them at this stage. That will come later if I decide to move ahead and look seriously at the acquisition of Brustlin. What I did want to do was find what was happening in the marketplace and discover how some of the small firms are competing.

\section{ASCALE BEVERAGE CORPORATION}

\section{History}

- Ascale Beverage Corporation was incorporated in 1998 and, in late 2000, began the sales and marketing of the first all-natural, lightly favored, still (non-carbonated) bottled spring waters, called VitaLife. In January 2003, the company introduced a line of all-natural, low calorie spring water beverages, formulated and packaged specifically for children. This line was called VitaDay.

\section{Ascale's Strategy}

- $\quad$ According to various market reports, Ascale's product line is based on the observation that "children in the United States are heavier than ever, and it is a dangerous trend. Overweight kids are at risk for cardiovascular disease, diabetes, and other diseases. While water is recognized as an aid in weight control, most of us don't drink enough of it. Why? Plain water is boring, difficult to drink. But, high-calorie sodas and exotic beverages with artificial everything are dangerous and unhealthy substitutes."

- $\quad$ The company's product line consists of seven low-calories fitness waters (with names such as Thunderball Rage and Typhoon Tea) that are bacteria-free and contain no preservatives. The VitaDay products line taste sweet but contain less than 15 calories per serving.

- Ascale distributes through Safeway, Vons, Dominick's, Pavilions, Randalls, Tom Thumb, Carr's and Genuardis where the products are introduced within the store' all-natural theme stores. They also sell through Shaw's Supermarkets and Wild Harvest all-natural stores than serve more than 2 million customers per week."

- $\quad$ Among the distributors for Ascale are Health Brands Inc. which is the largest marketer and distributor of allnatural foods - with 16 distribution facilities - servicing over 15,000 retail stores in the U.S. and Canada and United Natural Foods, the largest publicly traded wholesale distributor with over 7,000 customers in 50 states through its 11 distribution centers."

- In terms of pricing, the fitness waters are available from the company's web site at a cost of $\$ 31.95$ for 24 bottles half liter $(16.9 \mathrm{oz})$ bottles. At this time, the VitaPlay line is not available online.

- The company would not provide any information as to its advertising and promotional strategies. However, it does promote its product line at trade shows.

\section{The Future}

- According to Ascale's president and chief executive officer, the company anticipates excellent market response among youths and parents who seek healthier lifestyles for growing children." Although the most recent revenue figures suggest that Ascale has total sales of little more than a million dollars, industry observers suggest that, "looking forward, the company has secured valuable shelf space, which is expected to generate sales revenue in excess of $\$ 7$ million for the coming year. The company is perfectly positioned to dominate the 'all-natural' segment of the $\$ 100$ billion beverage industry!" 


\section{BERTRAND BOTTLING CO.}

\section{History}

- $\quad$ Founded in 1891, Bertrand Bottling Company began selling birch beer and flavored sodas. At the end of prohibition, the owners saw an opportunity to sell beer and alcoholic beverages and didn't want to deal with birch beer so, in 1934, Marcus Bertrand acquired that business. However, competition became extremely tough in the bottle business and he discontinued bottling and focused on selling birch beer in kegs.

- The grandson, Alan Bertrand, took over in the 80s and started manufacturing fountain syrups for colas. That business became very difficult when Coca Cola started a division and started to dominate the market. So, he looked around for new opportunities and decided there was a market for gourmet sodas. By August 1993, their first bottle of Bertrand's original birch beer hit the shelves. Marketing in kegs was discontinued around the same time.

- $\quad$ Today, Bertrand Bottling Company does approximately $\$ 5$ million annually.

\section{Bertrand Bottling Co's Strategy}

- In terms of the product, Bertrand produces syrup for its 10 flavor of soda (including black cherry - their number one seller - orange, grape, and ginger ale), two birch beers and a diet birch beer at its Waterford, Massachusetts location. All products are caffeine free. The syrup is then shipped to Trenton, New Jersey where the bottles are filled, crowned, and then shipped (either back to Clifton or direct to distributors).

- $\quad$ According to Alan Bertrand, the company offers a quality product. It uses cane sugar in place of corn syrup. While it is more expensive, he feels it produces a better product. Likewise, they use top quality flavors to produce a superior product.

- $\quad$ All Bertrand products are sold in the company's own 12 oz. glass bottles with raised lettering and a painted label. While it is much less expensive to use cans or plastic bottles, the company thinks their bottle creates a better image, one that (hopefully) resonates with those who, as children, grew up in a city and remember the bottled drinks. It is designed to be a classy bottle that customers will associate a classy product.

- $\quad 40-45 \%$ of the company's sales occur in the metropolitan Boston area. The company distributes the products itself within this area. Outside the area, it is in virtually every major market nationwide. However, outside Boston a network of local distributors handles distribution.

- It sees its major national competitors as being Stewart's Root Beer, IBC Root beer, and Wyatt-Caso Soda plus a large number of small regional firms.

- Unlike Coca Cola and Pepsi, Bertrand does not emphasize sales through supermarkets and vending machines. They feel they are not set up to service them. Specifically, they don't have the people or the volume of business to go into a supermarket and fill up the shelves on a daily basis. They do work with a few supermarket but only if they are willing to carry the inventory and handle the shelves.

- Most of the company's customers are pizzerias, delis and gourmet shops. They tend to be the high end of the market and want to offer something special. They also work with Starbucks (as an exclusive suppliers of a couple of flavors) and Applebee's where they have an exclusive arrangement in that their flavors are sold in bottles whereas coke, diet coke, etc. is dispensed from a pump.

- $\quad$ The company admits that, price-wise, their products are more expensive than firms like Coca-Cola and Pepsi. However, while they are at the top of the price scale, they don't feel their prices are prohibitive since there are more expensive products on the market. According to Alan Bertrand, they price their products to appeal to those consumers who want a premium product and are willing to pay a premium for it.

- $\quad$ Bertrand currently does relatively little advertising and promotion. They used to do some 30 -second t.v. spots that ran on cable that were reasonably successful. They also did some radio spots but found this wasn't too effective if people couldn't recognize the product. In recent years, most of the company's promotion at trade shows. Potential buyers come to these shows and sample our various products.

- The company also has a growing relationship with Costco. We set up on Wednesday and Thursday and then have a three-day road show. It gives people a chance to try the product and get to recognize the bottle. 
- $\quad$ The company does not have its own web site. However, it does have a relationship with a number of distributors with we sites and its products can be purchased through these firms.

\section{The Future}

- $\quad$ The company has recently negotiated an infusion of capital, which will enable it to expand its operations. The president feels they have the potential to become a $\$ 50$ million company within five years or so. According to Alan Berman, the company's main weakness is that it doesn't have a cola or a diet cola.

\section{CRESSMAN BOTTLING USA}

\section{History}

- Cressman Bottling USA entered the soft drink market in 1937 with a birch beer. Originally sold in barrels, the company soon expanded into bottles and cans. The current owners, who also distribute a number of major beer brands were a major distributor for Cressman and took over operations in the late 80s.

\section{Cressman's Strategy}

- Cressman currently offers seven flavors: sarsaparilla, orange cream, black cherry, cream soda, red birch beer, lemon cream, and root beer. All products are sold in 12oz. bottles and root beer, red birch beer, and orange cream area sold in 1 liter glass bottles.

- $\quad$ According to the Executive Vice President, Roger Keegan, all its sodas are caffeine free and have very low sodium. Cressman uses multiple blends in its extracts, which is more expensive. While they use corn syrup in their $12 \mathrm{oz}$ bottles (which are pasteurized and thus contain no preservative), the 1-liter bottles contain cane sugar and a preservative.

- $\quad$ The bottles come from Mexico. Cressman manufactures the syrup in Philadelphia and then it then goes to four bottling plants (one in Massachusetts, Two in Ohio and one in North Carolina) and then to its distributors across the country. The one liter dark brown bottle (or barrel) is the company's own design with an expensive label. The goal is to create a quality image.

- The company emphasizes old-fashioned traditional flavors. It doesn't offer a cola or a diet cola ... and have no intention of doing so. As Roger Keegen observed, "our goal is to 'keep under the radar' of the Coca Cola and Pepsi. We have a great cola formula but that is not where we want to go."

- Cressman sells through a network of distributors and also direct to a large retailers such as Target, Wal-Mart, Public and Albertson's. It is represented in most of the major markets across the United States where the product goes to delis, bagel places, and independent convenience stores. The company prides itself on offering a gourmet soda that provides higher margins for retailers. For example, a four pack of $12 \mathrm{oz}$ bottles costs $\$ 2.49$.

- $\quad$ The company sees Stewart's (which is owned by the Snapple Group), Bertrand and Wyatt-Caso Soda as its major competition ... although they feel that Wyatt-Caso is more of a Generation X marketers.

- $\quad$ The company's advertising and promotion is limited to print advertisement in trade magazines and displays at trade shows. They do some in-store ad but rely heavily on taste testing in stores.

- The company is talking to Costco about doing a road show in their locations. According to Roger Keegan, they want people to have the opportunity to try the product and say, "I like that. It tastes like the drinks I remember."

- $\quad$ Also, the company gets a lot of feedback from its press releases that always produce a lot of calls.

- The company has a very active web site and believes this is a great way to get to people. In addition to the listing of its products and the connection to Netgrocer.com, it also have a "What's New" section and a "Cressman Bottling Sighting" section where we post photographs of people with its products. Apparently, customers send the photos in and the company awards prizes such as T-shirts, etc. People also use the site to give the company feedback and comments. 


\section{The Future}

- Roger Keegan stated that they are trying to grow but not so fast as to attract attention. He explained that the industry leaders don't seem to be terribly successful at introducing new products so they are going the acquisition route ... and suspects that many of the smaller bottlers are trying to grow in order to make themselves attractive acquisition targets. Cressman wants to grow through increasing its distribution.

- However, there is a problem with this strategy in that Cressman is being cut out at the distributor level. It used to distribute through bottlers of A\&W Root Beer. However, they were acquired by Cadbury-Schweppes and that company has a policy of not allowing distributors to sell competitive flavors.

- $\quad$ "Some of the independent distributors may be interested but they have forgotten how to sell," Mr. Keegan commented. "They just service the local market. We are hoping for the growth of a new way of distribution. In the mean time, we continue to build up our own. We believe that people want to be different. They want a unique product. We also believe that kids drink what you drink ... and, if they see their parents drinking Cressman Bottling, they will do so."

\section{PRADA BRANDS INC.}

\section{History}

- $\quad$ According to the company's web site, Prada Brands was founded by Martin Prada in 1996.

- $\quad$ The genesis of the company (according to a New Business magazine article) arose because Mr. Prada (a rock climber and outdoor enthusiast) began to pay more attention to his health. He started shopping at naturalfood stores, buying organic fruits and vegetables, and taking vitamins. According to the article, it all fitted together. "The single most important thing you can do to improve the quality of life is to drink more water and Mr. Prada didn't want it to be just any water. He wanted it to be better water." "All of the innovation in beverages had come from entrepreneurs," Mr. Prada commented. After all, Snapple was started by three childhood friends who sold natural juices. Nantucket Nectars and Arizona Iced Tea have similar stories."

\section{Prada Brand's Strategy}

- $\quad$ According to an online newsletter, "Prada Brands is proud of its liquid assets. The company is making waves with its Crassile Water, a line of low-calorie flavored water enhanced with electrolytes and other nutrients."

- $\quad$ Prada Brands products are available in three varieties under the Crassile name: HealthyTimes (which has extra electrolytes, the minerals your body loses during perspiration) was introduced in 1996. Two years later, the company introduced FruitTime, which has no electrolytes, calories or preservatives but did have some added fruit flavoring. Then, in 2000, the company introduced VitaminTime, which has stronger flavors than the previous products, plus added vitamins and hard-to-miss candy colors.

- $\quad$ The company started selling its HealthyTimes products through health-food specialists ... first in St. Louis and then nationwide. It followed the same approach with the FruitTimes line. According to a New Business article, instead of targeting health nuts, the company went mainstream with the VitaminTime line. As Mr. Prada observed, "Once they had tried it, people said they wanted it everywhere - in universities, health clubs, spas, hotels, delis, grocery stores, gas stations, bodegas, etc."

- $\quad$ The company puts a lot of emphasis on quality packaging, which Mr. Prada feel is as important as what is in the bottle. Mr. Prada owned a boat that had been designed by a famed architect and, at a reception approached this same gentleman and asked him to help design Crassile's first bottle. Instead of just labeling his drinks with boring names like lemon or honeydew, he decided to give each type a "hip" moniker, such as orange-flavored Total Phase and Raspberry-Lemon Burst The labels also have catchy copy: 'For best results, mix with individuals showing signs of sluggishness and laziness. Warning: if severe procrastination occurs, buy a whole case."

- The company's advertising and promotion are also unique. The company bought billboards in St. Louis and advertisements in national magazines, including CosmoLife and InVogue. Martin Prada's strategy worked. According to the New Business article, you started to see the trendy people on the streets of Manhattan with a bottle of VitaminTime in hand. 
- $\quad$ The New Business points out, however, that "for all its popularity, the stuff might not actually be very good for you. Each 20-ounce bottle (which sells for about \$1.50) contains 125 calories and 32.5 grams of sugar, which is a lot for something that claims to be a health drink. Skeptical nutritionists have questioned whether products like these can even be called 'water,' but the International Bottled Water Association, a trade group, allows companies to add flavors and colors as long as they account for less than $1 \%$ of the content."

- In terms of the marketplace, Crassile is currently second only to Nestlé's Poland Spring. Its other major competitors are Danone Water and Red Bull. Its success has, however, attracted big-name competitors. Gatorade was the first of the large beverage companies to enter the market, introducing its Propel Fitness Water in July 1999. Similarly, Pepsi introduced its flavored Aquafina Essentials in grocery stores this past June. And the newest entrant in the enhanced-water race is Coca-Cola, which launched its Dasani NutriWater in three test markets in November. If that catches on, Coke plans to go nationwide in the spring.

\section{The Future}

- $\quad$ According to New Business, Mr. Prada welcomes such competition with good cheer. "The fact that bigger beverage companies are copying us means they think we know better than they do," he says, pausing to chuckle. "Which, of course, we do." The marketing buzz he's been able to generate should help too. Now that he has conquered Manhattan, Mr. Prada s next stop is completing the move into Hollywood. He enjoys offering his drinks at what he calls "lifestyle events." A recent ploy was to provide beverages for the Entertainment Tonight-sponsored Emmy Awards party at the Hayes Hotel in Los Angeles.

\section{WYATT-CASO SODA CO.}

\section{History}

- $\quad$ The history of the company goes back to 1987 when Andrea Casowski founded Caso Distributors and began distributing fruit juices. In 1995, she created her own products and started marketing bottled waters. Then, in August 2000, she merged with the Wyatt Soda Company to form the Wyatt-Caso Soda Co.

\section{Wyatt-Caso Soda's Strategy}

- In 1995, the company began with six flavors (such as Lemon-Line and Strawberry) and later added additional flavors with memorable names such as TangTang Lemon and Crushed Raspberry Blast. Then, in 2000, the company introduced Fast Eddie Energy Drink and, the following year, a line of Wyatt Natural (Fun-Loving Carrot and Wu-Wu's Desire).

- With the exception of the energy drinks (which are sold in $8.4 \mathrm{oz}$. aluminum cans) and the natural teas and juices (20-ounce glass bottles), the products are sold in $12 \mathrm{oz}$. bottles. As the web site states, "while unique bottles and imported water have been successful in the past, Wyatt-Cosa believes that these features increase production costs and reduce the ability of a manufacturer to respond quickly to any changes in the market. So, Wyatt-Cosa provides a stock bottle that is both cost effective and convenient and its labels and support materials have been designed for efficient, low-cost production."

- $\quad$ According to Thomas Walters, Executive Vice President, "we are a fashion conscious refreshing beverage company. But fashion is beauty and beauty is in the eye of the beholder. We let our customers tell us what is cool. Our niche is the 12 to 24 -year old beverage consumer who is into anything from photography to extreme sports and rock $\mathrm{n}$ roll. They are tech savvy, skeptical, education, racially diverse, and have spending power."

- The unique aspect of the labeling, however, is that the labels are continually changed based on ideas generated and submitted by its consumers. According to Brand Insights, Wyatt-Caso offers individuals and consumers a "create-your-own-label" option for special occasions. These include weddings, birthdays, shareholder's meetings, trade shows, or just for the fun of it. As Mr. Walters explains, "Our photo program is vital. When one photo makes a bottle, that person will tell everyone they know about it. The people they tell will tell a few more, and some will take the time to send in their own photo. That is an emotional connection. You inspire someone to get off their ass and become part of something fun. Furthermore, we have patented 
the right to customize and order branded merchandise over an Internet server. Branded merchandise!! Any branded merchandise!!"

- $\quad$ Distribution of Wyatt-Caso Soda began with what it calls its "alternative distribution strategy." The company placed its own coolers, bearing its signature logo, in some truly unique venues such as skate, surf and snowboarding shops, tattoo and piercing parlors, as well as individual fashion stores and national retail clothing and music stores. Following the execution of this strategy, Wyatt began an up and down the street attack on the marketplace; this time placing product in convenience and food stores. Finally, the company has now begun to achieve larger chain store listings with companies such as Starbucks, Safeways, Albertson's, and 7-11 stores. While the number of distributors nationwide is confidential, its products can be found in most major markets across the nation.

- $\quad$ In the same article, Brand Insights identified Wyatt-Caso Soda Co. as partnering with Fresh Bread Inc. to sell co-branded drinks at its specialty fresh bread and sandwich cafes. The custom labels feature black-and-white photos of bakery and related products and the text on the back pays tribute to the bakers who "go to great measures every night kneading, scoring and baking."

- Wyatt-Caso Soda doesn't do any traditional marketing. It displays its products at fancy food shows, convenience store shows, and surf and skate expos." The company also sponsors "extreme" athletes, surfboarders, and skateboarders. These athletes can be seen promoting Wyatt-Caso and sporting the WyattCaso logo at extreme sporting events across the country. It also has a number of large orange RV's covered in the company logo, which travel throughout cities in North America handing out soda and talking to the people in the street.

- $\quad$ As far as pricing is concerned, Wyatt-Caso Soda appears to be somewhere between Coca Cola and Pepsi at one end to the scale and the bottlers who use expensive ingredients such as cane sugar and unique glass bottles. "We like to be priced at 99 cents per bottle," Thomas Walters observed. "A pragmatic pleasure."

\section{The Future}

According to Mr. Walters, "the future is bright and tasty."

\section{REFERENCES}

1. National Soft Drink Association, www.nsda.org/SoftDrinks/History/funfacts.html.

2. Top-10 Soft Drink Companies and Brands for 2002, www.beverage-digest.com/pdf/top-10 2003.pdf.

3. Information provided by Beverage Digest, March 14, 2003, from the Fact Book 2001, p. 36.

4. Leading National Advertisers, Advertising Age, June 24, 2002, www.adage.com/images/random/lna2002.pdf. 


\section{Instructor's Manual: What Have I Learned?}

\section{CASE OVERVIEW}

Peter Caswell had always viewed the families bottling business as his birthright. He was stunned when his father sold the business while he was still in college. After becoming a successful personal injury lawyer with a bright future, he learns of the Brustlin Bottling Company that was for sale. In the case Peter reviews with Alan Dawes, his long time friend, information he has developed on five successful companies in the boutique soft drink bottling business. He is trying to decide his next steps a strategy to employ in the business.

\section{INTENDED AUDIENCE}

This case was written for use in a basic marketing course. More specifically it would be positioned at the point in the course during which niche marketing is discussed. The case material lends itself to use in a strategy or entrepreneurship course also. The teaching notes do not reflect these possibilities.

\section{CASE LEARNING OBJECTIVES}

This case is intended to enable the student to:

- $\quad$ Examine a market with well-defined niches

- $\quad$ Analyze different approaches to establishing a niche based on specific elements of the marketing mix

- $\quad$ Evaluate these companies' strategies against optimal niche characteristics

- $\quad$ Review the prospects of the firms in an industry dominated by giants.

\section{DISCUSSION QUESTIONS \& TEACHING APPROACH}

Since this case would normally be discussed very early in a marketing course, it is suggested that the class begin with a very general question that allows all students to participate. Each discussion prompt or question will become progressively harder and begin to separate the students by capability.

\section{What are some of the environmental factors that create the opportunity for niche marketing?}

Many factors have led to the fragmentation of this industry that provides opportunities for niche marketing. Dalgic and Leeuw listed the following:

- $\quad$ Single parent households, families with double incomes and no children, yuppies;

- $\quad$ Working women, overweight people, and tall people;

- $\quad$ Increasing minority markets;

- Technological advances;

- $\quad$ The evolution of consumer countervailing power;

- $\quad$ Changing demographic and lifestyles;

- $\quad$ The demands on personal time;

- $\quad$ Overcrowding of too many products, services and stores;

- $\quad$ The weakening of the magic in network television advertising;

- $\quad$ The decline in brand loyalty;

- $\quad$ Advertising clutter, overkill and waste; and 
- $\quad$ Feeding the discount promotion monster. ${ }^{1}$

What are some of the ways of defining niche markets that may be useful here?

After encouraging allowing the students to discuss this issue, the instructor may wish to present three different perspectives. Dalgic and Leeuw defined a niche market as a:

Small market consisting of individual customers or a small group of customers with similar characteristics or needs. ${ }^{1}$

By contrast, Chalasani and Shani defined it as:

Carving out a small part of the market whose needs are not fulfilled. By specialization along market, customer, product or marketing mix lines, a company can match the unique needs. ${ }^{2}$

And Massey viewed it as:

An organization's position or role within its market or field - the space occupied by an organization within its environment. ${ }^{3}$

What are the strategies being employed by the companies?

\section{Product}

Product differentiation is the strategy that comes closest to the traditional view of niche marketing. Bertrand Bottling and Cressman Bottling have focused on marketing flavors that appeal to the older generation who developed a liking for soft drinks prior to the growth of the industry giants. Ascale Beverage and Prada Brands have developed products aimed at the health conscious that are looking for a product that tastes better than plain water and contains relatively few calories and no preservatives.

\section{Ingredients}

The ingredients used by each firm were consistent with their market niche. Bertrand Bottling and Cressman Bottling utilize more expensive materials, which is consistent with the high quality image that they seek. Ascale Beverage, Prada Brands and Wyatt-Caso Soda were less concerned with ingredients since they are clearly aiming at a less expensive and more price conscious market niche.

Packaging

Bertrand Bottling, Cressman Bottling and Prada Brands have distinctive packages. Bertrand and Cressman felt that using a distinct bottle or label adds to the image of the product. Prada Brands did so because of their belief that packaging is as important as contents. Wyatt-Caso Soda has adopted a unique approach in that labels can be customized with whatever picture the customer desires.

\section{Distribution}

Due to the control of the main distribution channels by the majors, slotting fees etc., the niche firms have all resorted to alternate channels. Bertrand Bottling Co. focuses on pizzerias, delis and gourmet shops that wont to offer something special. Cressman Bottling follows a similar strategy. Wyatt-Caso has adopted its alterative distribution strategy. It places its own coolers in truly unique places such as skate shops, surf and snow boarding shops, tattoo and piercing parlors, etc. It follows its customers. 


\section{Pricing}

Pricing strategy is consistent with the niche strategy employed by each of the competitors. Bertrand and Cressman have adopted a premium price strategy, which is consistent with the perception of quality, which they hope to achieve. The other competitors price their product above the major competitors (i.e., Coca Cola and PepsiCo) but below that of Bertrand and Cressman.

\section{Are these firms targeting markets that meet Kotler's criteria for appropriate niches?}

At this point in the class, the instructor may wish to hand out a sheet listing Kotler's five (5) criteria for appropriate niches, namely:

- $\quad$ The customers in the niche have a distinctive set of needs.

- $\quad$ Customer will pay a premium to a firm that best satisfies their needs.

- $\quad$ The niche is not likely to attract other competitors.

- $\quad$ The niche gains certain economies of scale through specialization.

- $\quad$ The niche has size, profit and growth potential. ${ }^{4}$

And then ask the students whether or not the firms described in this case are, in fact, targeting markets that meet these criteria.

The customers in the niche have a distinct set of needs.

Ascale and Prada Brands clearly focused on the health conscious and the 'all natural segment of the beverage market. Bertrand and Cressman both targeted the nostalgia crowd that remembered the old fashioned products. Wyatt-Caso targeted the Generation Y creating products that appeal to them and speak their language.

Customers will pay a premium to a firm that best satisfies their needs.

Bertrand and Cressman have found a segment of the market that will pay a high price for nostalgia. Ascale, Prada Brands and Wyatt-Caso have placed their products in locations where the customer is interested in the product itself and thus is far less price sensitive.

The niche is not likely to attract other competitors.

The niches in this market are rather small and, in general, are unlikely to be large enough to attract either of the majors. However, Prada Brands has obviously developed a market of interest to Coca Cola and PepsiCo. Other niche player might represent a threat. However, with the regional nature of such competition and the multiplicity of channels of distribution, the threat seems small.

The niche gains certain economies of scale through specialization.

In none of the five companies is there any evidence of economies of scale through specialization.

The niche has size, profit and growth potential.

While they are mini-niches they certainly have the size required to be very profitable without being even noticed by the majors. The same is true for growth. 


\section{SHOULD PETER CASWELL PURSUE THIS OPPORTUNITY FURTHER?}

Some students will probably focus on the fact that Peter Caswell currently has a very successful career as a lawyer and would be making a serious mistake to give up his professionalism and life style to overcome his perceived rejection by his father more than ten years earlier. They will argue that the soft drink industry is dominated by a small number of major firms and he is never going to have the resources to compete with them. "Forget it" may well be their conclusion.

Other students may have a different perspective. They will probably conclude that there is opportunity in the niche soft drink bottling business. As long as Peter Caswell doesn't go head-to-head with the big guys, he could probably carve out a niche for himself. They nay also suggest that people should follow their instincts and that, since Peter has always wanted to be in this industry, he should take a serious look at the purchase of the Brustlin Bottling Company ... especially in terms of the total investment and the likely economics. They will argue that he has very little to lose.

\section{WHAT POSSIBLE NICHE STRATEGIES MIGHT PETER EMPLOY IF HE DECIDES TO GO AHEAD WITH THE PURCHASE OF BRUSTLIN?}

Students should be encouraged to brainstorm the possible strategies (in terms of product, ingredients, packaging, distribution, pricing and promotion) that Peter could employ.

While there is no single strategy in the materials presented by the five companies, students should be encouraged to put together a consistent approach to the market.

\section{REFERENCES}

1. Dalgic, T. and Leeuw, M., Niche Marketing Revisited: Concept, Applications and Some European Cases, European Journal of Marketing, Bradford, Vol. 4, 1994, pp. 39-52.

2. Chalasani, S. and Shani, D., Exploiting Niches Using Relationship Marketing, The Journal of Consumer Marketing, Vol. 9 No. 3, pp. 33-42.

3. Massey, J. E., 2001. Managing Organizational Legitimacy: Communication Strategies for Organizations in Crisis, Journal of Business Communication, 38(2):153-83.

4. Kotler, P., From Mass Marketing to Mass Customization, Planning Review, September - October, 1991, pp. 1147. 